The Journal of Development and Administrative Studies, Vol. 22, No. 1-2, pp. 1-14, 2014
() CEDA/TU, 2000, US Library of Congress, Catlog Card No.: 79-915209, ISSN: 2091-0339

\title{
Cash Management in Nepalese Manufacturing Enterprises
}

- Dilli Raj Sharma*

\begin{abstract}
A firm that requires external financing can rely on either debt or equity, but both have an asymmetric information problem which may prevent obtaining financing. In the case of debt financing, the higher the level of informational asymmetry between the firm and the lender, the more difficult it will be for the lender to ascertain the firm's credit quality. In some cases, identifying a firm's quality may be so difficult that the lender may simply ration credit. Because of this asymmetry in lending and the possibility of credit rationing by banks, firms may decide to hold high levels of cash so they can take advantage of positive net present value (NPV) projects even when credit is tight. However, if a firm holds cash, it should not need as much bank financing as it otherwise would. Thus the bank may incur a cost by encouraging cash holdings, namely the loss of potential loans to those firms. Hence, Cash management is the process whereby the cash inflows and outflows are controlled so that current obligations will be met in time and any excess cash will earn income. Specifically, it aims at determining the level of cash holdings by Nepalese manufacturing enterprises. With this in mind, samples of Nepalese manufacturing firms have been used to conduct a study with secondary data. First, regression model is used to test for the existence of an optimal cash holding in this study. The study based on twelve manufacturing enterprises covering the period 1999-2012. The study is reveals that cash holdings are positively affected by the investment opportunity set and cash flows while negatively affected by asset's liquidity, interest rate, leverage and size in Nepalese manufacturing enterprises.
\end{abstract}

Keywords: Cash management, dividend payment, liquidity assets, and investment opportunities

JEL classification numbers: G10, G21 and G28

\section{Introduction}

Firms have important cash holdings on their balance sheets, as has been demonstrated in recent studies. Investment in liquid assets has an opportunity cost for the firm due to their low return, particularly if the firm forgoes more profitable

Dr. Sharma is an Associate Professor, Central Department of Management, Kirtipur, Tribhuvan University Email: dr7sharma@yahoo.com 
investment to hold that level of cash. Today, when cash, like any other asset of the company, is a tool for profits, the emphasis is on the right amount of cash at the right time, at the right place, and at the right cost. Thus, cash is comparable to any other asset and, just like a piece of cloth or a bolt, you must have it when you need it. If you do not have cash, you must go out and borrow cash at the market price. Therefore, cash items management is a planned and not a spontaneous process. One plans what the needs are and how these needs are to be met.

The complexity and volatility of the business environment, as well as the need to protect cash from erosion and to control its use and allocation, dictate the need for effective cash management. Much of the literature on cash reserves is older and either descriptive or concerned with corporate transaction demand for cash. However, the role of cash in the corporation is much broader (Harford, 1999). In the presence of capital market imperfections deriving from asymmetric information between managers and capital providers, liquidity can take on a strategic role. Managers can increase firm value by managing their cash balances as buffer stocks. However, cash reserves have large potential costs in addition to their benefits. Biais and Gollier (1997) posit that frequent trips to the capital markets help control the agency conflict between shareholders and managers.

Kim, Mauer and Sherman (1998) demonstrate that US firms with higher cash levels show more growth opportunities, more volatility in their cash flows and less profitability in their productive assets. Opler, Pinkowitz, Stulz and Williamson (1999) obtain similar results for the same market, finding that smaller firms with more investment opportunities and risky activities possess a larger proportion of liquid financial assets. Ferreira and Vilela (2004) report that there are three theoretical models that can help to explain the firm's characteristics that influence cash holdings decisions. The main cost of holding cash is the opportunity cost of the capital invested in liquid assets. Second, the pecking order theory of Myers (1984) supported by the theoretical foundation of Myers and Majluf (1984) states that, to minimize asymmetric information costs and other financing costs, firms should finance investments first with retained earnings, then with safe debt and risky debt, and finally with equity. This theory suggests that firms do not have target cash levels, but cash is used as a buffer between retained earnings and investment needs. The study of the determinants of corporate cash holdings has not been very appealing in the past, judging by the different studies available on this subject. However, recent empirical studies have made good progress in their attempt to find the factors that explain the significant amount of cash and equivalent assets held by the firms. The major issue of this study is: Does the size of investment in cash vary across different enterprises over time and what factors affect the variations in the size of cash holdings in Nepalese enterprises? 
The main objective of this study is to examine the status of corporate cash management and ascertain the factors affecting thereof Nepalese manufacturing enterprises. Hence, the priori hypothesis for this study is that the size of cash holdings is affected by growth opportunities, size of the firm, opportunity cost (interest), cash flow, long term debt, leverage, financial distress and bank debt. This study is also expected to contribute to the literature as it identifies the factors affecting as well as position of cash holdings in Nepalese enterprises.

The rest part of this study is organized as follows:

In the next section (2), an extensive review of cash management and its determinants is presented. The model and data for cash management are presented in section 3. Section 4 contains the analysis of data and results. Finally, a discussion over the results is presented in section 5 .

\section{A Brief Review of Empirical Evidence}

The roles of cash forecasting, cash management accountability, and the elements affecting disbursement and collection time intervals are outlined, including generally accepted management principles and techniques. However, liquid assets have traditionally been justified for transaction motives, to meet the needs that come from the firm's normal activities, as well as for precautionary motives, to help meet unforeseen requirements for cash (Baumol, 1952; Miller and Orr, 1966; Meltzer, 1993; and Mulligan, 1997). Minimizing idle cash funds can do as much for the owners of a business firm as maximizing return on new investment projects (Singhvi and Kaupisch, 1970).

Cash holdings are positively associated with firm level risk, but negatively related to industry risk. Consistent with past researches, cash holdings are found to be decreasing with the firms' size and debt ratio and increasing with its profitability, growth prospects, and dividend payout ratio (Cressy, 1996). Kim, Maur, and Sherman(1998) demonstrate that US firms with higher cash levels show more growth opportunities, more volatility in their cash flows and less profitability in their productive assets.

Opler et al. (1999) indicate that firms with strong growth opportunities, higher business risk, and smaller size hold more cash than other firms. Firms hold excess cash to ensure that they will be able to keep investing when cash flow is too low, relative to investment needs, and when outside funds are expensive. With respect to the agency theory, Opler et al. (1999) find little evidence of the managerial entrenchment hypothesis as an explanation for the level of cash holdings. In this regard, a different issue has been raised by Pinkowitz and Williamson (2001) about the relationship between bank debt and cash holdings. Their finding suggests that 
Japanese firms have higher levels of cash balances due to higher power of banks and the absence of other monitor forces such as large non-bank block holders or an active market for corporate control. Similar results are found using a sample of US small firms (Faulkender, 2004) and a sample of UK firms (Ozkan and Ozkan, 2004). In contrast, Ozkan and Ozkan (2004) find that bank- debt financing has a negative impact on cash levels for UK firms, consistent with banks having less power.

Contrary to the agency view, capital markets development has a negative impact on cash levels (Ferreira and Vilela, 2004). This study points out that growth opportunities and the variability of cash flows are positively related to cash holdings, while leverage, dividend payments and liquid assets substitutes indicate lower cash holdings. Teruel and Solano (2009) highlights when the interest rates in the economy increase firms reduce their cash holding. Different studies investigating the effects of asymmetric information on corporate cash holdings (Kim et al., 1998; Opler et al., 1999; Dittmer et al., 2003; Ferreire and Vilela, 2004; Ozkan and Ozkan, 2004; Teruel and Solano, 2008) reveal that cash holdings are positively related to the degree of asymmetric information related to growth opportunities, size, debt maturity and banking relationships. In summary, firms with higher growth opportunities, smaller size, and shorter debt maturity and less bank debt are expected to hold higher levels of cash.

In this regard, limited studies have been conducted so far to test the above hypothesis relating to the factors affecting of cash holdings by Nepalese enterprises. Some old studies are not relevant in the changing context of Nepal. This study tests the models that will either support or reject the Ozkan \& Ozkan (2004), Opler-Ferreira and Vilela (2004), Nguyen (2005) and Teruel and Solano (2009). This study therefore concentrates towards dealing with the factors affecting of cash holdings of Nepalese enterprises.

\section{The Study Methodology}

\subsection{Samples and data}

According to the Annual Performance Review of Public Enterprises, 2010 of Ministry of Finance, only seven from public enterprises and 18 from listed companies are under manufacturing sector in Nepal. Since this study has been directed towards assessing various aspects of the problem over a period of time, all the manufacturing enterprises established in Nepal cannot provide scope for their study as some of them are at the stage of liquidation and some are unable to provide data for the last different years. Because of the specific nature of their activities, firms relating to service sectors and others like banking and finance, insurance etc. are excluded from this study. Hence, in this study, judgmental, 
random, convenient and stratified sampling techniques are combinely used. For the purpose of this study, twelve manufacturing enterprises are selected for the analysis, out of which five enterprises are from the public sector and seven enterprises are from the private sector. The information required for the sample is taken from the Auditor General and System of Analysis of Balance Sheets database, developed by Security Board of Nepal (SEBON), Ministry of Finance, Nepal Rastra Bank, Central Beauro of Statistics (CBS) etc. The firms have been selected from the manufacturing sector during the period of analysis (1999-2012).

\subsection{The model}

The corporate cash holdings is regressed on investment opportunity, liquid assets, $\mathrm{Z}$ score, leverage, size, cash flow, and debt maturity and gross domestic products (GDP). The regression is based on the model analysed by Opler et al. (1999), Ozkan and Ozkan (2004), Ferreira and Vilela, (2004) and Teruel and Solano (2009).

The final model for the determinant of cash balance is,

$$
\begin{aligned}
& \mathrm{CASH}_{i t}=\alpha+\delta_{0} \mathrm{CASH}_{i t-1}+\delta_{1} \mathrm{SGR}_{i t}+\delta_{2} \mathrm{SIZE}_{i t}+\delta_{3} \mathrm{SIZE}_{2 i t}+\delta_{4} \mathrm{BANKD}_{i t}+ \\
& \delta_{5} \mathrm{ZSCORE}_{i t}+\delta_{6} \mathrm{LEV}_{i t}+\delta_{7} \mathrm{LTD}_{i t}+\delta_{8} \mathrm{CFLOW1}_{i t}+\delta_{9} \mathrm{CFLOW1}_{i t}+\delta_{1} \mathrm{OLIQ}_{i t} \\
& +\delta_{11} \mathrm{INT}_{\mathrm{it}}+\delta_{12} \mathrm{GDP}_{i t}+E_{i t}
\end{aligned}
$$

In this analysis the level of cash is determined estimating two models.

$$
\begin{aligned}
& \mathrm{CASH}_{1}=\alpha+\delta_{0} \mathrm{CASH}_{i t-1}+\delta_{1} \mathrm{SGR}_{i t}+\delta_{2} \mathrm{SIZE}_{i t}+\delta_{3} \mathrm{SIZE}_{2 i t}+\delta_{4} \mathrm{BANKD}_{i t}+ \\
& \delta_{5} \mathrm{ZSCORE}_{i t}+\delta_{6} \mathrm{LEV}_{i t}+\delta_{7} \mathrm{LTD}_{i t}+\delta_{8} \mathrm{CFLOW}_{i t}+\delta_{9} \mathrm{CFLOW}_{i t}+\delta_{1} \mathrm{OLIQ}_{i t}+ \\
& \delta_{11} \mathrm{INT}_{\mathrm{it}}+\delta_{12} \mathrm{GDP}_{i t}+E_{i t \ldots \ldots \ldots . .4 .1}
\end{aligned}
$$

and

$\mathrm{CASH}_{2}=\alpha+\delta_{0} \mathrm{CASH}_{i t-1}+\delta_{1} \mathrm{SGR} i t+\delta_{2} \mathrm{SIZE}_{i t}+\delta_{3} \mathrm{SIZE}_{2 i t}+\delta_{4} \mathrm{BANKD}_{i t}+$

$\delta_{5} \mathrm{ZSCORE}_{i t}+\delta_{6} \mathrm{LEV}_{i t}+\delta_{7} \mathrm{LTD}_{i t}+\delta_{8} \mathrm{CFLOW}_{i t}+\delta_{9} \mathrm{CFLOW}_{i t}+\delta_{1} \mathrm{OLIQ}_{i t}+$ $\delta_{11} \mathrm{INT}_{\mathrm{i} t}+\delta_{12} \mathrm{GDP}_{i t}+E_{i t \ldots \ldots \ldots . .2}$

Where,

$\mathrm{CASH}_{1}=$ the ratio of cash plus marketable securities to total assets; $\mathrm{CASH}_{2}=$ the ratio of cash plus marketable securities to total assets less cash and marketable securities; $\mathrm{SIZE}_{1}=$ natural logarithm of sales; $\mathrm{SIZE}_{2}=$ the natural logarithm of assets; $\mathrm{BANKD}=$ level of short-term bank debt; $\mathrm{ZSCORE}=$ probability of financial distress; $\mathrm{LEV}=$ the leverage; $\mathrm{LTD}=$ debt maturity structure $\mathrm{CFLOW}_{1}=$ dividing pre-tax profits plus depreciation over sales; $\mathrm{CFLOW}_{2}=$ dividing pre-tax profits plus depreciation total assets; $\mathrm{LIQ}=$ investment in other liquid assets; $\mathrm{INT}=$ interest rates; GDP $=$ Gross domestic product 


\subsection{Specification of variables}

Cash holdings: In this study, cash ratio has been taken as the ratio of cash and cash equivalents to net assets, where net assets are computed as book value of assets, less cash and equivalents (Opler et al., 1999). Cash holding ratio is dependent variable. The priori hypothesis in this case is that cash holdings are positively affected by the investment opportunity and cash flows are negatively affected by liquidity, leverage and size.

The dependent variable used in this study has been measured in two ways. First, and similarly to Ozkan and Ozkan (2004), the variable $\mathrm{CASH}_{1}$ is used and it is calculated as the ratio of cash and marketable securities to total assets. Second, the variable $\mathrm{CASH}_{2}$ is used, which is identical to CASH1 except that in the denominator cash and marketable securities are subtracted from the total assets (Opler et al., 1999). The higher the values of both these measures, the higher the firm's cash level.

Growth opportunities: The existence of growth opportunities in firms is an important factor that positively affects cash levels, as has been shown in various empirical studies (Kim et al., 1998; Opler et al., 1999; Ferreira and Vilela, 2004; Ozkan and Ozkan, 2004 and Teruel and Solano, 2008).

Investment opportunity: The cost of incurring in a cash shortage is higher for firms with a larger investment opportunity set to the expected losses that result from giving up valuable investment opportunities. Therefore, a positive relation is expected between investment opportunity and cash holdings.

Liquid Assets: To the extent that liquid assets other than cash can be liquidated in the event of a cash shortage. They can be seen as substitutes for cash holdings. Consequently, firms with more liquid assets substitutes are expected to hold less cash.

Leverage: It is generally accepted that leverage increases the probability of bankruptcy due to the pressure that rigid amortization plans put on the firm's treasury management. To reduce the probability of experiencing financial distress, firms with higher leverage are expected to hold more cash. Thus, the predicted relationship between cash holdings and leverage is ambiguous.

Size: To measure size two proxies are used. First, the $\mathrm{SIZE}_{1}$, which is calculated as the natural logarithm of sales, and on the other $\mathrm{SIZE}_{2}$, the natural logarithm of assets. This would lead larger firms to hold less cash than smaller firms.

Cash flow: The cash flow has been approximated by dividing pre-tax profits plus depreciation over sales $\left(\mathrm{CFLOW}_{1}\right)$ or total assets $\left(\mathrm{CFLOW}_{2}\right)$. It is expected that 
firms with larger cash flows to hold more cash. Thus, the expectation is a negative relation between cash flows and cash holdings.

Debt maturity: If considering that firms with the highest credit rating have better access to borrowing, it is expected that these firms will hold less cash for precautionary reasons, which would cause debt maturity to be positively related to cash holdings.

Financial distress: The likelihood of financial distress is calculated according to the re-estimation of Altman's (1968) model carried out by Begley, Mings and Watts (1996), given by the following expression:

$$
\text { Z- SCORE }=0.104 * X_{1}+1.010 * X_{2}+0.106 * X_{3}+0.003 * X_{4}+0.169 * X_{5}
$$

Where $X_{1}=$ Working capital/Total assets; $X_{2}=$ Retained earnings/Total Assets; $X_{3}=$ Net operating profits/Total assets; $X_{4}=$ Book value of capital/Book value of debt; $X_{5}=$ Sales $/$ Total assets.

Although the ratio $X_{4}$ is calculated as market value of capital over book value of debt in the original model, the alternative as proposed by Scherr and Hulburt (2001) - the book value (and not the market value) of the assets has been used. This is because the market value is not available in the case of Nepalese enterprises. A higher ZSCORE implies a lower default risk.

Gross domestic product: Finally, the gross domestic product (GDP) growth has been introduced to measure the possible effects of the evolution of the economic cycle on cash levels.

\section{Data Analysis and Findings}

\subsection{Descriptive statistics}

In order to characterize the firms of the sample, Table 4.1 reports the descriptive statistics of the variables used. It can be seen that the sample is made up of small firms, with average assets of Rs.44.76 million and average sales of Rs.14.08 million. They are levered in an average with debt of $72 \%$. Bank debt represents almost $48 \%$ of these firms' debt. In addition, their long term debt making up only, $32 \%$ of their external financing. The average cash holding of Nepalese firms is $5.3 \%$ of total assets $\left(\mathrm{CASH}_{1}\right)$ and $7 \%$ if cash and marketable securities are subtracted from total assets $\left(\mathrm{CASH}_{2}\right)$. 
Table 4.1

Descriptive statistics of variables affecting the size of cash

\begin{tabular}{|c|c|c|c|c|c|c|c|}
\hline \multirow{2}{*}{ Variables } & \multirow{2}{*}{ Mean } & \multirow{2}{*}{ Median } & \multirow{2}{*}{ Std. Deviation } & \multirow{2}{*}{ Minimum } & \multirow{2}{*}{ Maximum } & \multicolumn{2}{|c|}{ Percentiles } \\
\hline & & & & & & 10 & 90 \\
\hline $\mathrm{CASH}_{1}$ & 0.053 & 0.035 & 0.075 & 0.001 & 0.566 & 0.005 & 0.155 \\
\hline $\mathrm{CASH}_{2}$ & 0.071 & 0.065 & 0.171 & 0.001 & 1.65 & 0.004 & 0.155 \\
\hline GROWTH & 0.113 & 0.15 & 0.376 & -1 & 2.64 & -0.255 & 0.555 \\
\hline SALES & 611.225 & 415.58 & 476.739 & 14.08 & 2664.58 & 65.15 & 1254.11 \\
\hline ASSETS & 809.41 & 504.81 & 1494.978 & 44.76 & 6614.72 & 105.15 & 1660.35 \\
\hline BANKD & 0.478 & 0.353 & 0.259 & 0.042 & 2.698 & 0.579 & 0.756 \\
\hline Z-SCORE & 0.317 & 0.123 & 0.357 & -0.493 & 1.681 & 0.059 & 0.654 \\
\hline LEV & 0.717 & 0.51 & 1.52 & 0 & 6.28 & 0.51 & 1.475 \\
\hline $\mathrm{CFLOW}_{1}$ & -0.377 & 0.065 & 5.553 & -64.775 & 4.608 & -0.1506 & 1.634 \\
\hline $\mathrm{CFLOW}_{2}$ & 0.113 & 0.062 & 1.304 & -4.258 & 1.465 & -0.075 & 0.634 \\
\hline LIQA & 0.436 & 0.363 & 4.28 & 0.425 & 1.61 & 0.059 & 0.856 \\
\hline INT & 5.426 & 6.63 & 1.743 & 4.5 & 6.34 & 3.95 & 6.56 \\
\hline LDEBT & 0.318 & 0.169 & 0.216 & 0.14 & 0.69 & 0.052 & 0.541 \\
\hline
\end{tabular}

\subsection{Determinants of cash holdings in Nepalese enterprises}

In order to determine the relationship between cash holdings and other independent variables, the Pearson correlation coefficients have been computed and the results are presented in the form of correlation matrix in Table 4.2. In general, it can be said that the correlations between the firms' cash holdings and the explanatory variables have the expected sign, except for the variable measuring the opportunity cost (interest), growth opportunities, and size even if opportunity cost (interest), cash flow, long term debt, leverage, financial distress (Z-SCORE), bank debt, and size $_{2}$ are not statistically significant. 
Table 4.2

Correlation matrix of cash management based on 12 manufacturing enterprises

\begin{tabular}{|c|c|c|c|c|c|c|c|c|c|c|c|c|c|}
\hline Factors & $\mathrm{CASH}_{1}$ & $\mathrm{CASH}_{2}$ & SGR & Size1 & Size2 & BANKD & ZSCORE & LEV & LTD & $\mathrm{CFLOW}_{1}$ & $\mathrm{CFLOW}_{2}$ & LIQA & INT \\
\hline $\mathrm{CASH}_{1}$ & 1 & & & & & & & & & & & & \\
\hline $\mathrm{CASH}_{2}$ & $.769 * *$ & 1 & & & & & & & & & & & \\
\hline SGR & -.113 & -.073 & 1 & & & & & & & & & & \\
\hline SIZE $_{1}$ & $.215^{* *}$ & .239 & $\begin{array}{l}- \\
.242 * *\end{array}$ & 1 & & & & & & & & & \\
\hline SIZE $_{2}$ & .127 & .113 & $-.142 *$ & $.667 * *$ & 1 & & & & & & & & \\
\hline BANKDEBT & .121 & .133 & -.074 & .076 & $-.224 * *$ & 1 & & & & & & & \\
\hline ZSCORE & .021 & .034 & .024 & $.167^{*}$ & -.083 & -.004 & 1 & & & & & & \\
\hline LEV & -.041 & -.033 & .124 & -.077 & $-.264 * *$ & .044 & $-.284 * *$ & 1 & & & & & \\
\hline LTD & -.111 & -.093 & -.057 & .096 & $.378^{* * *}$ & $-.204 * *$ & -.103 & $.216 * *$ & 1 & & & & \\
\hline $\mathrm{CFLOW}_{1}$ & -.021 & -.039 & .095 & .0165 & .075 & -.054 & .0074 & $-.157 *$ & .036 & 1 & & & \\
\hline $\mathrm{CFLOW}_{2}$ & .121 & .131 & .055 & $.167 *$ & $.284 * *$ & -.034 & $.234 * *$ & $-.617 * *$ & .001 & $.161^{*}$ & 1 & & \\
\hline LIQA & $-.216^{*}$ & $-.138^{*}$ & .075 & $-.167 * *$ & $-.534 * *$ & $.408 * *$ & $.435 * *$ & -.077 & $-.246^{*}$ & -.003 & .021 & 1 & \\
\hline Interest & \begin{tabular}{|l|}
-.012 \\
\end{tabular} & \begin{tabular}{|c|}
-.038 \\
\end{tabular} & .085 & $-.169^{*}$ & -.107 & -.054 & -.066 & -.026 & -.048 & $-.151 *$ & -.041 & -.021 & 1 \\
\hline
\end{tabular}

** Correlation is significant at the 0.01 level (2-tailed). * Correlation is significant at the 0.05 level (2-tailed).

First, firms with better growth opportunities should have larger cash holdings. The results show that the variable SGR is positive in most of the estimations carried out in Table 4.3 but they are not statistically significant. Of the four regressions shown in Table 4.3, three have the expected sign and are not significant. This result is similar to that of Kim et al. (1998), Opler et al. (1999) and Ozkan and Ozkan (2004) and Teruel and Solano (2008) for large firms but not consistent in our Table 4.4 results. 
Table 4.3

Factors affecting of cash holdings in Nepalese enterprises (Cash ${ }_{1}$; Dependable variable)

\begin{tabular}{|c|c|c|c|c|c|c|c|c|c|c|c|c|}
\hline \multirow{2}{*}{\begin{tabular}{|l|} 
Models \\
Variables \\
\end{tabular}} & \multicolumn{3}{|l|}{1} & \multicolumn{3}{|l|}{2} & \multicolumn{3}{|l|}{3} & \multicolumn{3}{|l|}{4} \\
\hline & coef. & t- value & p-value & coef. & t- value & p -value & coef. & t-value & p-value & coef. & t-value & p - value \\
\hline Constant & .013 & .380 & .734 & .052 & 1.294 & .197 & -.011 & -.295 & .569 & -.012 & -.324 & .746 \\
\hline $\operatorname{Cash}_{1 \mathrm{t}-1}$ & .624 & 10.624 & .001 & .679 & 11.774 & .000 & .751 & 9.782 & .000 & .547 & 10.622 & .000 \\
\hline SGR & .003 & .191 & .848 & $\begin{array}{l}9.92 \mathrm{E}- \\
005\end{array}$ & .008 & .894 & .005 & .373 & .608 & .003 & .213 & .833 \\
\hline Size $_{1}$ & .005 & .798 & .436 & & & & .003 & .827 & .410 & .003 & .723 & .463 \\
\hline Size $_{2}$ & & & & -.002 & \begin{tabular}{|l|}
-.487 \\
\end{tabular} & .627 & & & & & & \\
\hline BANKD & -054 & -1.938 & .003 & -.076 & -3.196 & .002 & -.051 & -2.887 & .004 & -.041 & -2.909 & .004 \\
\hline Z SCORE & .030 & 1.819 & .051 & .035 & 1.211 & .029 & .030 & 1.834 & .068 & .030 & 1.820 & .071 \\
\hline LEV & .004 & 2.572 & .001 & .007 & 1.791 & .001 & .005 & 1.982 & .000 & .007 & 1.244 & .001 \\
\hline LTD & -.016 & -.502 & .516 & -.062 & -2.812 & .003 & -.014 & -.546 & .486 & .202 & 2.212 & .053 \\
\hline $\mathrm{CFLOW}_{1}$ & .072 & 4.101 & .006 & .043 & 1.213 & .004 & 0.034 & 3.253 & .001 & & & \\
\hline $\mathrm{CFLOW}_{2}$ & & & & & & & & & & .109 & 3.151 & .003 \\
\hline LIQA & -.077 & -3.338 & .001 & -.090 & -2.541 & .001 & -.077 & -5.352 & .001 & -.078 & -4.372 & .001 \\
\hline INT & & & & & & & -.001 & -.109 & .513 & \begin{tabular}{|l}
$-1.93 \mathrm{E}-$ \\
005
\end{tabular} & -.007 & .993 \\
\hline GDP & & & & & & & .006 & 1.905 & .048 & .006 & 1.878 & .063 \\
\hline $\begin{array}{l}\text { R-sq. Adj } \\
\text { D W test } \\
\text { Eigen Value } \\
\text { Index Factor }\end{array}$ & \begin{tabular}{|l|}
.621 \\
1.971 \\
3.110 \\
9.371 \\
\end{tabular} & & & \begin{tabular}{|l|}
720 \\
1.974 \\
4.078 \\
11.389 \\
\end{tabular} & & & \begin{tabular}{|l|}
532 \\
1.992 \\
6.851 \\
13.782 \\
\end{tabular} & & & \begin{tabular}{|l|}
.553 \\
1.977 \\
6.968 \\
14.003 \\
\end{tabular} & & \\
\hline
\end{tabular}

It reflects positive relationship between cash holdings and size of the firm in most of the regressions in Tables 4.3 and 4.4. However, size does not appear to affect cash levels, since most of the coefficients estimated for the variables SIZE $_{1}$ and $\mathrm{SIZE}_{2}$ are not significant. Previous studies by Kim et al. (1998), Guney et al. (2003) and Ozkan and Ozkan (2004), Teruel and Solano (2008) have not confirmed the idea that smaller firms maintain higher cash levels either, in spite of the intuitive attraction of the argument that small firms have greater information asymmetry problems, financial difficulties or financial constraints that make it more difficult and more expensive for them to obtain external financing. This may be because, as Ozkan and Ozkan (2004) point out, other factors may affect the way in which a company's size affects its cash holding decisions. 
Table 4.4

Factors affecting of cash holdings in Nepalese enterprises (Cash ${ }_{2}$, dependable variable)

\begin{tabular}{|c|c|c|c|c|c|c|c|c|c|c|c|c|}
\hline \multirow{2}{*}{\begin{tabular}{|l|} 
Models \\
Variables \\
\end{tabular}} & \multicolumn{3}{|l|}{1} & \multicolumn{3}{|l|}{2} & \multicolumn{3}{|l|}{3} & \multicolumn{3}{|l|}{4} \\
\hline & coef. & t-value & p-value & coef. & t-value & p -value & coef. & t-value & p-value & coef. & t-value & p -value \\
\hline Constant & .005 & .096 & .924 & .123 & 1.490 & .266 & -.005 & -.075 & .741 & -.010 & -.113 & .612 \\
\hline $\operatorname{Cash}_{2 t-1}$ & .063 & 1.314 & .061 & .045 & 1.535 & .045 & .062 & 2.806 & .063 & .063 & 1.475 & .053 \\
\hline SGR & -.004 & -.323 & .624 & -.025 & -.607 & .513 & -.005 & -.157 & .878 & -.012 & -.331 & .796 \\
\hline SIZE $_{1}$ & .014 & 1.371 & .106 & & & & .013 & 2.261 & .209 & .012 & 1.036 & .202 \\
\hline SIZE $_{2}$ & & & & -.004 & -.682 & .530 & & & & & & \\
\hline BANKD & -.133 & -3.132 & .001 & -.144 & -2.519 & .002 & -.121 & -2.093 & .002 & -.130 & -2.099 & .002 \\
\hline ZSCORE & .073 & 2.972 & .051 & .094 & 1.544 & .012 & .059 & 1.462 & .051 & .076 & 1.913 & .057 \\
\hline LEV & .005 & 1.141 & .139 & .003 & 1.302 & .851 & .006 & 1.640 & .813 & .005 & 1.453 & .000 \\
\hline LTD & -.068 & -2.331 & .002 & -.103 & -2.582 & .003 & -.062 & -2.311 & .003 & -.042 & -.619 & .453 \\
\hline $\mathrm{CFLOW}_{1}$ & .065 & 3.452 & .003 & 0.054 & 1.281 & .001 & .064 & 3.361 & .005 & & & \\
\hline $\mathrm{CFLOW}_{2}$ & & & & & & & & & & .1358 & 1.16 & .003 \\
\hline LIQA & -.211 & -2.772 & .000 & -.250 & -3.135 & .000 & -.110 & -3.457 & .000 & -.209 & -2.756 & .000 \\
\hline INT & & & & & & & -.001 & -.109 & .914 & -.002 & -.031 & .575 \\
\hline GDP & & & & & & & .004 & .502 & .538 & .004 & .244 & .387 \\
\hline R-sq. Adj & \multicolumn{3}{|l|}{.636} & \multicolumn{3}{|l|}{.737} & \multicolumn{3}{|l|}{.735} & \multicolumn{3}{|l|}{.829} \\
\hline DW test & \multirow{3}{*}{\multicolumn{3}{|c|}{$\begin{array}{l}2.333 \\
3.412 \\
9.929\end{array}$}} & \multirow{3}{*}{\multicolumn{3}{|c|}{$\begin{array}{l}2.454 \\
3.342 \\
9.343\end{array}$}} & \multirow{3}{*}{\multicolumn{3}{|c|}{\begin{tabular}{|l|}
2.994 \\
6.148 \\
14.331 \\
\end{tabular}}} & \multirow{3}{*}{\multicolumn{3}{|c|}{\begin{tabular}{|l|}
3.432 \\
6.257 \\
11.536 \\
\end{tabular}}} \\
\hline Eigen Value & & & & & & & & & & & & \\
\hline Index Factor & & & & & & & & & & & & \\
\hline
\end{tabular}

On the other hand, and as predicted, it has been observed that the coefficient of the variable BANKD is significant and negative in all regressions in both Tables 4.3 and 4.4. Moreover, this relationship has considerable economic impact. This appears to indicate that maintaining a banking relationship improves access to this type of external financing by reducing the information asymmetry between borrower and lender. In this way, and as is confirmed empirically by Ferreira and Vilela (2004) and Ozkan and Ozkan (2004), and Teruel and Solano (2008) that firms that are more highly indebted to credit institutions can reduce their investments in liquid financial assets.

The positive sign in the coefficient estimates on LEV indicate the opposite (the most highly leveraged firms have higher cash holdings). The coefficient of the variable measuring financial distress (Z-SCORE) is significant. Hence, there appears a relationship between the likelihood of default and cash holdings. The coefficient of the variable LDEBT is significant with a negative sign. Significant coefficients have an important economic impact given that a one standard deviation increase on the proportion on long-term debt over total debt is associated with a reduction in cash holdings. Specifically, the coefficient estimates on cashflow (pretax profits plus depreciation over sales and total assets respectively) are positive and statistically significant and it indicates that firms generating larger cash flows 
possess greater cash holdings, as expected.

On the other hand, the most important economic significance is for the presence of other liquid assets that may substitute for cash. The relationship between cash holdings and asset liquidity (LIQA) is negative and significant in all the regressions. Finally, in order to evaluate the effect of changes in the macroeconomic environment over time on cash holdings, the interest rates (INT) and gross domestic product (GDP) are also included in the variables. This variable is not significant, which may be explained by the fact that the period studied belongs to a single economic cycle.

\section{Result and Discussion}

The aim of this work is also to examine the determinants of the cash holdings in Nepalese enterprises. With regard to the effects deriving from the existence of market imperfections, the results appear to indicate that firms with more information asymmetry hold more liquid assets. Indeed, bank debt is associated with lower levels of cash, which supports the idea that relationships with credit institutions can reduce agency costs and information asymmetry between borrowers and lenders, thereby cutting a firm's cost of external financing. Equally, firms with a greater capacity to generate cash flows possess higher cash holdings. In addition, the existence of growth opportunities appears to affect the decision to hold liquid assets, although with small economic impact. Moreover, the results partially support the hypothesis that firms with more short-term debt, which are therefore likely to have greater information asymmetry, also hold more cash. The most important economic impact is for the existence of substitutes for cash. This exerts a negative effect on firm's cash holdings, since possessing liquid assets reduces cash levels. On the other hand, this analysis finds little empirical support for the influence of leverage on firm's levels of cash. The result does not change while introducing interest rates in increments rather than levels.

The result appears to indicate that the cash holdings of corporations are negatively related with the interest rates in the general economy, since cash levels increase (decrease) when interest rates fall (climb). In fact, a reduction in interest rates in the Nepalese economy in the period of analysis is associated with a rise in the cash kept by firms, though with a limited economic impact. Though, it is not observed any relationship between GDP growth and cash levels, but this might be explained because the period analyzed belongs to a single cycle. Finally, it should be noted that this study has several limitations. First, as with any measures, different proxies of cash determinants are subject to certain limitations. Second, it focuses on some limited determinants but there are other attributes of earnings, such as persistence, predictability, timeliness and value relevance that can have an influence on cash 
holdings. Lastly, given the importance of cash management, more studies similar to this or covering a wider and different scope should be conducted from time to time which would provide further confirmation of the results reported in this study. The extension of this investigation to these different attributes of cash constitutes an interesting field of research for the future.

\section{REFERENCES}

Baumol, W. J. (1952). The transaction demand for cash: An inventory theoretical approach. Quarterly Journal of Economics, 65, 545-566.

Biais, B. \& Gollier, C. (1997). Trade credit and credit rationing, Review of Financial Studies, 10,903-37.

Cressy, R. (1996). Are business start-ups debt-rationed? The Economic Journal,106 (438),1253-1270.

Dittmar, A., Smith, J. Mahrt \& Servaes, H. (2003). International corporate governance and corporate cash holdings. Journal of Financial and Quantitative Analysis, 38,111-133.

Faulkender, M. (2004). Cash holding among small businesses. Working Paper, SSRN.

Faulkender, M., \& Wang, R. (2006). Corporate financial policy and the value of cash. Journal of Finance, 61, 1957-1990.

Ferreira, M. A. \& Vilela, A. (2004). Why do firms hold cash? Evidence from EMU countries. European Finance Management, 10, 295-319.

Ferris, S. J. (1981). A transactions theory of trade credit use. Quarterly Journal of Economics, 96, 243-270.

Harford, J. (1999). Corporate cash reserves and acquisitions. Journal of Finance, 54.

Kim, C. S., D. Mauer \& Sherman, A. E. (1998). The determinants of corporate liquidity: Theory and evidence. Journal of Financial and Quantitative Analysis, 33, 335-59.

Meltzer, A. H. (1960). Mercantile credit, monetary policy, and size of firms. Review of Economics and Statistics, 42, 429-37.

Meltzer, A. H. (1993). The demand for money: A cross-section study for business firms. Quarterly Journal of Economics, 77, 405-22.

Miller, M. H. \& Orr, D. (1966). A model of the demand for money by firms. Quarterly Journal of Economics, 80, 413-35. 
Mulligan, C. B. (1997). Scale economies, the value of time, and the demand for money: Longitudinal evidence for firms. Journal of Political Economy, 105,1061-79.

Myers, B. (2003). Principles of Corporation Finance. New Delhi: Tata McGraw Hill Publishing Company Private Limited.

Myers, S. C. \& Majluf, N. S. (1984). Corporate financing and investment decisions when firms have information those investors do not have. Journal of financial economics, 13, 187-221.

Myers, S. C. (1977). Determinants of corporate borrowing. Journal of Financial Economics, 5, 147-75.

Opler, T., L. Pinkowitz, S. R. \& Williamson, R. (1999). The determinants and implications of corporate cash holdings. Journal of Financial Economics, 52, $3-46$.

Opler, T., L. Pinkowitz, S. R. \& Williamson, R. (2001). Corporate cash holdings. Journal of Applied Corporate Finance, 14, 55-66.

Ozkan, A. \& Ozkan, N. (2004). corporate cash holdings: An empirical investigation of UK companies. Journal of Banking and Finance,28, 21032134.

Pinkowitz, L. \& Williamson, M. (2001). Bank power and cash holdings: Evidence from Japan. Review of Financial Studies, 4, 1059-1082.

Pinkowitz, L., Stulz, R. \& Williamson, R. (2003). Do firms in countries with poor protection of investor rights hold more cash? Working Paper, SSRN.

Singhvi, S. S. \& Kaupisch, J. A. (1970). Cash management in a developed economy. Economic and Political Weekly:5(35), Aug. 29, M95 + M97 + M99 - M100.

Teruel, P. J. G. \& Solano, P. M. (2008). On the determinants of SME cash holdings: Evidence from Spain. Journal of Business Finance and Accounting,35,127-49. 